\title{
JNPH
}

Volume 6 No. 1 (April 2018)

(C) The Author(s) 2018

\section{EFEKTIFITAS MIKROORGANISME LOKAL (MOL) REBUNG BAMBU SEBAGAI AKTIVATOR PEMBUATAN KOMPOS TAHUN 2014}

\author{
EFFECTIVENESS OF LOCAL MICROORGANISMS (MOL) REBUNG BAMBU AS A \\ MOTHER COMPOSTY ACTIVATOR IN 2014
}

\author{
HAIDINA ALI, DERI KERMELITA \\ DOSEN KESEHATAN LINGKUNGAN POLTEKKES KEMENKES BENGKULU \\ Email: alimanafh@gmail.com
}

\begin{abstract}
ABSTRAK
Latar belakang : pemeliharaan dan pelestarian lingkungan hidup tidak terlepas dari beberapa masalah, seperti terganggunya lingkungan hidup akibat penggunaan pupuk yang mengandung bahan kimia. Permasalahan lain yang sering dikeluhkan oleh pada petani adalah kelangkaan pupuk. Pupuk bersubsidi di Kota Bengkulu sering mengalami kelangkaan diakibatkan pengurangan jatah yang bersumber dari pemerintah pusat. Tujuan penelitian adalah untuk mengetahui efektivitas MOL dari rebung bambu sebagai alternatif dalam pembuatan pupuk kompos.Metode : jenis penelitian eksperimental dengan rancangan posttest only with control group design. Dengan empat perlakuan, yaitu penambahan dosis $15 \mathrm{ml}, 20 \mathrm{ml}, 25 \mathrm{ml}, 30 \mathrm{ml}$ dan empat pengulangan. Analisis data yang digunakan yaitu analisis univariat dan bivariat, dilanjutkan dengan uji Bonferonni.Hasil : ada perbedaan terhadap lama waktu pengomposan dengan penambahan aktivator MOL rebung bambu dosis $15 \mathrm{ml}, 20 \mathrm{ml}, 25 \mathrm{ml}$, dan $30 \mathrm{ml}$, dengan dosis $30 \mathrm{ml}$ merupakan dosis paling efektif dalam mempercepat pengomposan.Saran : diharapkan bagi masyarakat untuk dapat memanfaatkan rebung bambu sebagai alternatif baru dalam pembuatan aktifator pengomposan.
\end{abstract}

Kata Kunci Daftar Pustaka : Rebung Bambu, MOL, Aktivator

\begin{abstract}
Background : Maintenance and preservation of the environment can not be separated from some problems, such as environmental disruption caused by the use of fertilizers that contain chemicals. Another issue that is often complained of by the farmers are shortages of fertilizer. Subsidized fertilizer in Bengkulu city often experienced shortages caused by the allotment reduction come from central government. The purpose of the study was to determine the effectiveness of MOL as an alternative bamboo shoots in composting.Methods: The type of experimental research with only posttest design with control group design. With four treatments, namely the addition of a dose of $15 \mathrm{ml}, 20 \mathrm{ml}, 25 \mathrm{ml}, 30 \mathrm{ml}$ and four repetitions. Analysis of the data used univariate and bivariate analysis, followed by Bonferonni test.Results: no difference in the length of time composting with the addition of bamboo shoots MOL activator dose of $15 \mathrm{ml}, 20 \mathrm{ml}, 25 \mathrm{ml}$ and $30 \mathrm{ml}$, with a dose of $30 \mathrm{ml}$ was the most effective dose in accelerating the composting. Suggestion: expected for people to be able to utilize bamboo shoots as a new alternative in the making composting activator.
\end{abstract}

Keywords:Bamboo,Shoots,MOL,Activator 


\section{PENDAHULUAN}

Derajat kesehatan dan kualitas hidup manusia bergantung kepada kemampuan untuk menyikapi, mengelola hubungan timbal balik antara aktifitas manusia dengan lingkungan fisik dan biologinya. Dimuka bumi tidak ada satupun yang berdiri sendiri, semuanya

saling bergantung dan saling membutuhkan satu dengan yang lainnya. Oleh karena itu, diperlukan adanya wawasan mengenai Lingkungan, Ilmu Pengetahuan dan Teknologi (IPTEK) yang akan mengarah pada pemeliharaan dan pelestarian lingkungan hidup (Panjaitan, 2013).

Pemeliharaan dan pelestarian lingkungan hidup tidak terlepas dari beberapa masalah, seperti terganggunya lingkungan hidup akibat penggunaan pupuk yang mengandung bahan kimia. Pupuk kimia atau pupuk anorganik adalah pupuk yang terbuat dengan proses fisika, kimia, atau biologis. Pada umumnya pupuk anorganik dibuat oleh pabrik. Bahan-bahan dalam pembuatan pupuk anorgank berbeda beda, tergantung kandungan yang diinginkan. Misalnya unsur hara fosfor terbuat dari batu fosfor, unsur hara nitrogen terbuat dari urea (Ulin, 2011).

Penggunaan pupuk kimia secara terus menerus yang diharapkan mampu meningkatkan kesuburan tanah justru menjadi penyebab menurunnya kualitas tanah. Tanah menjadi keras dan keseimbangan unsur hara dalam tanah pun terganggu. Seperti pada kasus di beberapa daerah di Indonesia, lahan pertanian mengalami kejenuhan fosfat dan kalium karena penggunaan pupuk NPK yang berlebihan dan tidak seimbang (Wahyono, 2011).

Pupuk anorganik mempunyai kelebihan dan kekurangan yang nyata. Kelebihan pupuk anorganik:

1. Hasil cepat terlihat pada tanaman

2. Kandungan unsur hara jelas

3. Mudah pengaplikasian

4. Tidak bau dan pengangkutan mudah
Kekurangan pupuk anorganik

1.Mengakibatkan residu pada tanah

2.Penggunaan tidak bijaksana dapat

3.Harga mahal

4.Bersifat higroskopis

Kelebihan-kelebihan pupuk anorganik tersebut sudah di ketahui petani di Indonesia, tetapi kekurangan pupuk anorganik hampir semua petani di Indonesia belum mengetahui, karena mereka sampai saat ini masih menggunakan pupuk anorganik secara besarbesaran yang berdampak pada tanah-tanah di Indonesia menjadi rusak dan ketergantungan pupuk anorganik pada petani (Ulin, 2011).

Permasalahan lain yang sering dikeluhkan oleh para petani adalah kelangkaan pupuk. Kepala Dinas Pertanian, Perkebunan, Kehutanan, dan Peternakan Kota Bengkulu, diwakili Kasi Sarana dan Prasarana, Marwan mengatakan kelangkaan pupuk bersubsididi Kota Bengkulu diakibatkan pengurangan jatah yang bersumber dari pemerintah pusat (KupasBengkulu.com).

Dalam RKPD (Rencana Definitif Kebutuhan Kelompok), jumlah pupuk bersubsidi yang diajukan kelompok tani di Kota Bengkulu di tahun 2014 untuk pupuk urea 1.247 ton, SP36 1.194 ton, ZA 366 ton, NPK 1.189 ton, dan organik 758 ton. Sedangkan berdasarkan Perwal No. 33tahun 2013, pupuk yang akan didistribusikan pada tahun 2014 untuk pupuk jenis Urea sebanyak 669 ton, SP36187 ton, ZA 35,4 ton, NPK 256,1 ton, dan organik 125,7 ton (KupasBengkulu.com).

Marwan mengungkapkan jumlah pasokan pupuk bersubsidi dari tahun ke tahun memang mengalami pengurangan. Berdasarkan koordinasi dengan Dinas pertanian Provinsi Bengkulu, hal ini terjadi karena pemerintah pusat menginginkan para petani tidak terus bergantung padapupuk subsidi ini. Petani yang diperbolehkan membeli pupuk bersubsidi hanyalah petani yang kelompoknya mengajukan RKPD, Rabu (14/05/2014). 
Masalah lain yang menyebabkan kelangkaan pupuk ialah pupuk bersubsidi ini dijatah berdasarkan keperluan perbulan dan tidak diperbolehkan melakukan penimbunan pupuk. Misalnya di bulan Januari belum musim bertanam, tentu mereka belum memerlukan pupuk. Namun petani tidak diperbolehkan membeli pupuk karena ditakutkan adanya penimbunan pupuk. Namun di bulan Februari saat musim tanam tiba, para petani akan berlomba-lomba mendapatkan pupuk,sedangkan distributor tidak bisa mengeluarkan pupuk melebihi jatah bulanan yang telah ditentukan. Hal inilah yang menyebabkan kelangkaan pupuk di kota Bengkulu masih sering terjadi dan belum bisa teratasi.

Dengan permasalahan tersebut, salah satu upaya yang bisa dilakukan untuk mengurangi dampak terhadap lingkungan dan kelangkaan pupuk akibat penggunaanpupuk anorganik adalah dengan pemanfaatan bahan organik yang ramah lingkungan dan murah yang bisa kita produksi sendiri. Pemanfaatan bahan organik yang dapat kita produksi sendiri dilakukan melalui pembuatan pupuk organik, seperti kompos dan pupuk kandang. Dengan adanya pembuatan pupuk kompos ini diharapkan dapat mengurangi dampak dari penggunaan dan kelangkaan pupuk kimia yang terjadi di Indonesia khususnya Provinsi Bengkulu.

Produk yang dapat dijadikan bahan pupuk organik adalah penggunaan MOL (mikroorganisme lokal) menggunakan rebung bambu. MOL adalah mikroorganisme yang dimanfaatkan sebagai starter dalam pembuatan pupuk organik padat maupun pupuk cair. Bahan utama MOL terdiri dari beberapa komponen yaitu karbohidrat,glukosa, dan sumber mikroorganisme. Bahan dasar untuk fermentasi larutan MOL dapat berasal dari hasil pertanian, perkebunan, maupun limbah organik rumah tangga. Karbohidrat sebagai sumber nutrisi untuk mikroorganisme dapat diperoleh dari limbah organik seperti air cucian beras, singkong, gandum, rumput gajah, dan daun gamal. Sumber glukosa berasal dari cairan gula merah, gula pasir, dan air kelapa, serta sumber mikroorganisme berasal dari kulit buah yang sudah busuk, terasi, keong, nasi basi, dan rebung bambu (Ria, 2012).

MOL rebung bambu mempunyai kandungan $\mathrm{C}$ organik dan giberellin yang tinggi sehingga mampu merangsang pertumbuhan tanaman secara cepat. Selain itu MOL rebung bambu juga mengandung mikroorganisme yang sangat penting untuk membantu pertumbuhan tanaman yaitu Azotobacter dan Azospirillium (Sani, 2013). Proses pengomposan yang biasanya memerlukan waktu yang sangat lama sekitar 2-4 bulan, dengan adanya proses pengomposan dengan menggunakan MOL sebagai aktivatornya, pengomposan bisa dipercepat menjadi 2-3 minggu (Panjaitan, 2013).

Penulis mencoba untuk memberikan inovasi baru dengan memanfaatkan bambu muda (rebung) yangEfektivitas MOL Rebung Bambu Dalam Pembuatan Kompos pada dasarnnya tidak digunakan oleh masyarakat sebagai bahan baku pembuatan kompos. Harapannya, disamping dapat menyediakan unsur hara bagi tanaman, penggunaan rebung bambu ini dapat menggantikan penggunaan pupuk anorganik yang dipakai oleh petani, sehingga penggunaan pupuk kompos ini jauh lebih murah dan ramah lingkungan. Berdasarkan uraian tersebut, maka dapat diambil suatu rumusan masalah sebagai berikut: Bagaimana efektivitas MOL rebung bambu dapat memberikan hasil yang lebih baik dan efisien sebagai bahan alternatif dalam pembuatan pupuk kompos ?Penelitian ini bertujuan untuk mengetahui efektivitas MOL dari rebung bambu sebagai alternatif dalam pembuatan pupuk kompos.

\section{ALAT DAN BAHAN}

Timbangan, Derigen/botol plastik, Pisau, Kayu pengaduk, Tutup ember, Soil meter, Termometer, Blender dan polybag ukuran $2 \mathrm{~kg}$, Pipa PVC, Alat tulis dan karung.

Larutan MOL rebung bambu yang 
sudah jadi, sampah organik pasar (sayuran hijau) $8 \mathrm{~kg}$, sekam padi $8 \mathrm{~kg}$, batang pisang 8 $\mathrm{kg}$, dan jerami $8 \mathrm{~kg}$.

\section{CARA KERJA}

Membuat formulasi dasar atau larutan mikroorganisme lokal (MOL) rebung bambu. Pada pembuatan mikroorganisme lokal (MOL) ini terjadi proses fermentasi yang berlangsung selama 10-14 hari.

Setelah 10-14 hari, hasil fermentasi berupa larutan mikroorganisme lokal (MOL) rebung bambu yang digunakan untuk memacu dalam mempercepat proses pengomposan. Kemudian dilanjutkan dengan pembuatan kompos dengan penambahan mikroorganisme lokal (MOL) rebung bambu yang telah dibuat. Data yang diperoleh dari hasil pengukuran dan pengamatan parameter pengomposan meliputi $\mathrm{pH}$, suhu, bau, dan warna kompos.

\section{HASIL}

\section{Analisis Univariat}

\section{Analisis univariat bertujuan}

Menggambarkan distribusi rata-rata masing-masing variabel yang dianalisi secara statistik deskriptif (Mean dan standar deviasi), yang disajikan dalam bentuk tabel dan distribusi rata-rata untuk mengetahui proporsi masing-masing variabel.

Lama waktu terbentuknya kompos dapat ditentukan melalui pengamatan terhadap $\mathrm{pH}$, suhu, bau dan warna kompos yang diamati setiap 3 hari sekali. Apabila kriteria kompos telah terpenuhi, maka kompos dapat dikatakan matang. Data waktu pengomposan dapat dilihat pada grafik 3.1.

Berdasarkan grafik 3.1 diperoleh hasil waktu pengomposan sampah organik sampai matang. Waktu yang paling efektif dalam terbentuknya kompos yaitu pada kelompok penambahan aktifator MOL rebung bambu dengan dosis $30 \mathrm{ml}$ yaitu selama 15 hari.
Grafik 1 Rata-Rata Waktu Pengomposan Pada Kelompok Kontrol Dan Perlakuan Waktu Terbentuknya Kompos

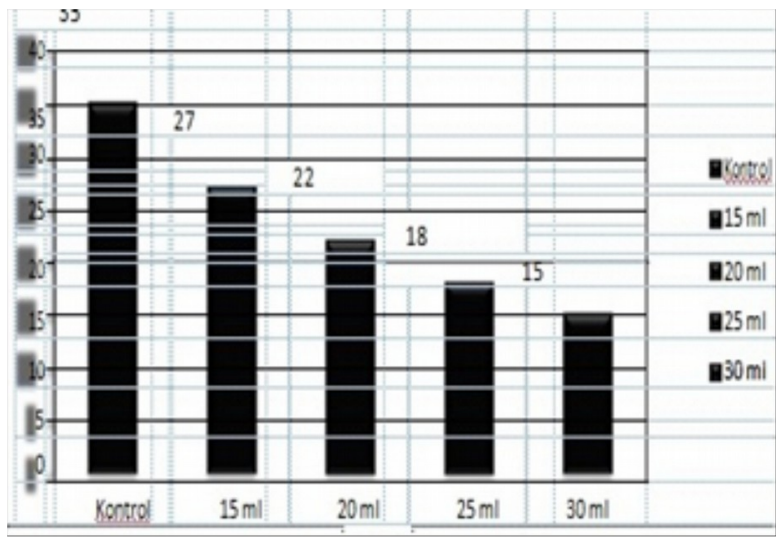

\section{Bau, Warna, dan Tekstur}

Rata-rata hasil pengukuran parameter fisik (bau, warna, dan tekstur) selama proses pengomposan pada kelompok kontrol dan kelompok perlakuan pada penambahan MOL rebung bambu sebagai aktivator dalam pembuatan kompos dapat dilihat pada tabel 1 .

Tabel 1. Rata-Rata Perubahan Bau, Warna, dan Tekstur Kompos Pada Kelompok Kontrol Dan Perlakuan

\begin{tabular}{|c|c|c|c|}
\hline \multicolumn{4}{|c|}{ Rata-Rata Perabahan Parameter Fisik (Bau Dan Wama) Pada Kompe } \\
\hline & Tidak Berball & Tidak Bervama & Berubah Téstur \\
\hline Bontrol & 19 hari & 15 hari & 17 hari \\
\hline Perlahen & $16 \mathrm{harg}$ & $12 \mathrm{hraj}$ & $13 \mathrm{hraj}$ \\
\hline
\end{tabular}

Data dari tabel tersebut menunjukkan bahwa rata-rata perubahan bau pada kelompok perlakuan terjadi dalam waktu 16 hari sedangkan untuk kelompok kontrol selama 19 hari. Rata-rata terjadi perubahan warna kompos pada kelompok perlakuan selama 12 hari dan kelompok kontrol selama 15 hari, sedangkan tekstur kompos pada kelompok perlakuan selama 13 hari dan kelompok kontrol selama 17 hari. 


\section{Analisis Bivariat}

Analisis bivariat dilakukan dengan uji One Way Anova untuk mengetahui perbedaan yang signifikan antara masing-masing variabel bebas dan variabel terikat. Hasil uji dapat dilihat pada tabel 2 .

Tabel 2 Distribusi Rata-Rata Waktu Pengomposan Pada Kelompok Perlakuan Dan Kontrol

\begin{tabular}{|c|c|c|c|c|c|}
\hline Variabel & Mean (Han') & Sd & \multicolumn{2}{|c|}{$95 \%, \mathrm{CL}$} & PValue \\
\hline \multicolumn{6}{|l|}{ Lama rakitu } \\
\hline terbentuknara kompos & & & LB & CB & \\
\hline Rontrol & 35.00 & 1.633 & 32.40 & 37.60 & \\
\hline Dosis $15 \mathrm{ml}$ & 27.00 & 0.816 & 25.70 & 2830 & \\
\hline Dosis $20 \mathrm{ml}$ & 22.00 & 0.816 & 20.70 & 2330 & 0.000 \\
\hline Dosis $25 \mathrm{ml}$ & 18.00 & 0.816 & 16.70 & 1930 & \\
\hline Dosis $30 \mathrm{ml}$ & 15.00 & 0.816 & 13.70 & 16.30 & \\
\hline
\end{tabular}

Berdasarkan tabel 2 diperoleh data bahwa rata-rata lama waktu terbentuknya kompos pada dosis $15 \mathrm{ml}$ adalah 27 hari dengan standar deviasi 1,633. Pada dosis 20 $\mathrm{ml}$ adalah 22 hari dengan standar deviasi 0,816. Pada dosis $25 \mathrm{ml}$ adalah 18 hari dengan standar deviasi 0,816 . Pada dosis 30 $\mathrm{ml}$ adalah 0,816.

Hasil uji statistik didapat nilai $\rho=$ $0,000<\alpha(0,05)$, berarti dapat disimpulkan ada perbedaan lama waktu terbentuknya kompos dengan penambahan larutan MOL rebung bambu dengan dosis $15 \mathrm{ml}, 20 \mathrm{ml}, 25$ $\mathrm{ml}$, dan $30 \mathrm{ml}$.

Untuk mengetahui perbedaan lama waktu terbentuknya kompos dari keempat perlakuan dengan menggunakan aktifator Mikroorganisme Lokal (MOL) rebung bambu dosis $15 \mathrm{ml}, 20 \mathrm{ml}, 25 \mathrm{ml}$, dan $30 \mathrm{ml}$ dilakukan uji Bonferonni.

Tabel 3. Signifikasi Perbedaan Rata-rata Waktu Pengomposan Kelompok Perlakuan dan Kontrol

\begin{tabular}{|c|c|c|c|}
\hline Peralkuan & & pralue & Kesimpulan \\
\hline \multirow[t]{4}{*}{ Bontoll } & Dosis $15 \pm 1$ & 0.000 & 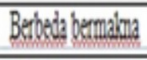 \\
\hline & Dosis $20 \mathrm{~m}$ & 0.000 & Berboda bemalua \\
\hline & Dosis 25 m & 0.000 & Berotad bemalang \\
\hline & Dosis 30 & 0.000 & Beroda bemaluas \\
\hline \multirow[t]{3}{*}{ Dosis $1.5 \mathrm{~m}$} & Dosis 20 m & 0.000 & Berotia bemalara \\
\hline & Dosis25 & 0.000 & Berboda be malma \\
\hline & Dosis30 & 0.000 & Berbeva bemalana \\
\hline \multirow[t]{2}{*}{ Dxisis 20m } & Dosis $25 \mathrm{~m}$ & 0.001 & Berbeta hemalowa \\
\hline & Dosis $30 \mathrm{~m}$ & 0.000 & Berbeta bemalua \\
\hline Dasis 25m & Dosis $30 \mathrm{ml}$ & 0.009 & Bertoda bermalus \\
\hline
\end{tabular}

Analisis lebih lanjut memperlihatkan bahwa ada perbedaan rata-rata lama waktu terbentuknya kompos dengan penambahan larutah MOL dosis $15 \mathrm{ml}, 20 \mathrm{ml}, 25 \mathrm{ml}$, dan $30 \mathrm{ml}$. Dari data tersebut dapat disimpulkan bahwa dosis penambahan larutah MOL yang paling efektif adalah dosis $30 \mathrm{ml}$.

\section{KESIMPULAN}

Berdasarkan hasil penelitian yang telah dilakukan, dapat simpulkan bahwa : Rata-rata selama 27 hari terbentuk pupuk kompos dengan penambahan aktivator Mikroorganisme Lokal (MOL) rebung bambu dengan dosis $15 \mathrm{ml}$. Rata-rata selama 22 hari terbentuk pupuk kompos dengan penambahan aktivator Mikroorganisme Lokal (MOL) rebung bambu dengan dosis $20 \mathrm{ml}$.

1. Rata-rata selama 18 hari terbentuk pupuk kompos dengan penambahan aktivator Mikroorganisme Lokal (MOL) rebung bambu dengan dosis $25 \mathrm{ml}$.

2. Rata-rata selama 15 hari terbentuk pupuk kompos dengan penambahan aktivator Mikroorganisme Lokal (MOL) rebung bambu dengan dosis $30 \mathrm{ml}$.

3. Terdapat perbedaan lama waktu terbentuknya pupuk kompos yaitu dosis $30 \mathrm{ml}$ lebih efektif dibandingkan dengan dosis $15 \mathrm{ml}, 20 \mathrm{ml}$, dan $25 \mathrm{ml}$ dalam mempercepat proses pengomposan. 


\section{SARAN}

Berdasarkan hasil yang telah dilakukan maka peneliti memberikan saran kepada :

\section{Bagi Masyarakat}

Masyarakat dapat memanfaatkan rebung bambu sebagai alternatif baru dalam pembuatan aktifator pengomposan.

\section{Bagi Institusi}

Hasil penelitian ini dapat dijadikan sebagai referensi baru yang diharapkan dapat bermanfaat bagi ilmu pengetahuan .

\section{Bagi Pelitian Lanjutan}

Bagi peneliti yang ingin melanjutkan penelitian ini diharapakan dapat membandingkan aktifator MOL dengan aktifator lainnya.

\section{DAFTAR PUSTAKA}

Alex. 2011. Sukses Mengolah Sampah Organik Menjadi Pupuk Organik. Yogyakarta: Pustaka Baru Press.

Atmaja, dkk. 2013. Analisis Kualitas Kompos Limbah Persawahan dengan MOL Sebagai Dekomposer". Skripsi, Universitas Udayana. Bali.

Bebeja. 2010. Ayo Produksi Rebung Bambu. Diakses dari http://www.bebeja.com/2010/12/23 /ayoproduksi-rebung-bambu/html._Diunduh tanggal 9 Maret 2014

Edowart. 2011. Pupuk Organik Cair MOL. Diakses dari http://edowartblogspotscom.blogsp ot.com/2011/10/pupuk-organik-cairmol.html. Diunduh tanggal 11 Maret 2014

Fendi. 2011. Kulit Singkong Sebagai Alternative Pembuatan Kompos.

Diakses dari http://fendi.blogspot.com/2011/06/k ulitsingkong-sebagai-alternative-pembuatan- kompos.html. Diunduh pada tanggal 7 Februari 2014.

Hidayat. 2012. Rebung Tanaman Mini Kaya Manfaat. Diakses dari http://agrobisnisdan-agroindustriindonesia/2012/12/23/rebungtanaman- mini-kaya-manfaat $/ \mathrm{html}$. Diunduh tanggal 9 Maret 2014

Iman, Anwar. 2010. Evaluasi Kritis Kebijakan Pupuk Bersubsidi Di Indonesia. Diakses dari http://anwariman.com/evaluasi-kritiskebijakan-pupuk-bersubsidi-diindonesia/.html. Diunduh tanggal 10 Maret 2014

Indriani, Yovita Hety. 2011. Membuat Kompos secara Kilat. Jakarta:

Penebar Swadaya. Isroi. 2008.

Pembuatan Pupuk Cair Organik Rebung Bambu. Diakses dari http://www.gerbangpertanian.com/2008/ 04/pembuatan-pupuk-cair-organik -rebung-bambu-7748/html. Diunduh tanggal 3 Februari 2014.

Kamari. 2012. Kompos (Pengertian dan Prinsip Dasar). Diakses dari http://chemistry35.blogspot.com/20 11/07/kompos-pengertian-dan-prinsipdasar.html. Diunduh tanggal 10 Maret 2014

Kamus Besar Bahasa Indonesia. Diakses dari http://kbbi.web.id/kompos. Diunduh tanggal 10 Maret 2014 Kumalasari, Yeti. 2013. Pengaruh Penambahan Dosis Bokashi Eceng Gondok Terhadap Lama Waktu Pengomposan Sampah Organik Pasar Panorama dan Sampah Organik Sisa Makanan Rumah Makan $S$ Kota Bengkulu. Karya Tulis Ilmiah, Poltekkes Kemenkes RI. Bengkulu.

Madzhaluna. 2009. Keunggulan dan Kekurangan Kompos. Diakses dari http://madzhaluna.blogspot.com/20 09/12/keunggulan-dan-kekurangankompos.html. Diunduh tanggal 11 Maret Maspary. 2012. Membuat MOL Rebung Bambu. Diakses dari http://www.gerbang pertanian.com/2012/05/membuat-mol- 
rebung-bambu.html.Diunduh tanggal 23 Januari 2014 pukul 11.14.. 2012. 3 Bahan Utama Pembuatan MOL. Diakses dari http://www. gerbangpertanian.com/2012/02/3-bahan-utamapembuatan-mol.html. Diunduh tanggal 26 Januari 2014.

Nurmanadi. 2012. Ayo Buat Mol. Diakses dari http://ceritanurmanadi.wordpress.c om/2012/11/27/ayo-buat-mol $/ \mathrm{html}$. Diunduh tanggal 9 Maret 2014

Rasyid. 2010. Tinjauan Pustaka Rebung. Diakses dari http://www.scribd.com/doc/2010/1 0/12/Tinjauan-pustaka-rebung/html. Diunduh tanggal 10 Maret 2014

Rusdi. 2011. Rebung Tunas Bambu yang Kaya Serat. Diakses dari http://rusdi.blogspot.com/2011/05/rebung -tunas-bambu-yang-kaya-serat- .html. Diunduh tanggal 8 Maret 2014

Sani. 2013. Kumpulan Tentang MOL Part II. Diakses dari http://sani.blogspot.com/2013/10/k umpulan-tentang-mol-part-ii.html. Diunduh tanggal 1 Februari 2014 pukul 15.00 .

Saputra, Andi. 2013. Pengertian Kompos Menurut Para Ahli. Diakses dari http://fourseasonnews.blogspot.co $\mathrm{m} / 2013 / 01 /$ pengertian-kompos-

menurut- para-ahli.html. Diunduh tanggal 10 Maret 2014

\section{Saryono. 2011. Metodelogi Penelitian Kesehatan. Jogyakarta: Mitra Cendikia Press.}

Sinaga, Damayanti. 2009. Pembuatan Pupuk Cair dari Sampah Organik Dengan Menggunakan Boisca sebagai Starter. Skripsi, Universitas Sumatera Utara. Medan.

Sobirin. 2010. Kompos yang Ramah
Lingkungan.
Diakses
dari
http://www.gerbangpertanian.com/
2010/12/12/kompos-yang-ramah-
lingkungan $/ \mathrm{html}$. Diunduh tanggal 10
Maret 2014

Suarapembaruan. 2014. Petani Muko-
Muko Kesulitan Pupuk Bersubsidi.

Diakses dari

http:/www.suarapembaruan.com/na sional/petani-mukomuko-kesulitan -pupuk-bersubsidi/. Tanggal 11 Maret 2014

Sudarso. 2009. Pembuangan Sampah. Yogyakarta: Pustaka Baru Press

Ulin. 2011. Pupuk Anorganik. Diakses dari http://ulin.blogspot.com/2011/11/pupukanorganik.html. Diunduh pada tanggal 20 Ferbuari 2014.

Wahyono, Sri, et al. 2011. Membuat Pupuk Organik Granul dari Aneka Limbah. Jakarta Selatan: PT. Agromedia Pustaka.

Widia, dkk. 2012. Praktik Baik Budidaya Bambu Rebung. Diakses dari http://share.Pdfonline.com/2012/12 / 3/praktik-baik-budidaya-bamburebung/.html. Diunduh pada tanggal 23 Januari 2014.

Widyasari. 2012. Tinjauan Pustaka Rebung. Diakses dari http://www. aristanovawidyasari.blogspot.com $/ 2$ 012/25/01/tinjauan-pustaka-rebung.html. Diunduh pada tanggal 11 Januari 2014. 